\title{
Reclassification of the genus Leuconostoc and proposals of Fructobacillus fructosus gen. nov., comb. nov., Fructobacillus durionis comb. nov., Fructobacillus ficulneus comb. nov. and Fructobacillus pseudoficulneus comb. nov.
}

\author{
Correspondence \\ Akihito Endo \\ pegaman@hotmail.co.jp
}

\author{
Akihito Endo ${ }^{1,2,3}$ and Sanae Okada ${ }^{1,4}$ \\ ${ }^{1}$ NODAI Culture Collection Center, Tokyo University of Agriculture, 1-1-1 Sakuragaoka, Setagaya, \\ Tokyo 156-8502, Japan \\ ${ }^{2}$ Division of Pharmacognosy, Phytochemistry and Narcotics, National Institute of Health Sciences, \\ Ministry of Health, Labour and Welfare, 1-18-1 Kamiyoga, Setagaya, Tokyo 158-8501, Japan \\ ${ }^{3}$ Department of Microbiology, University of Stellenbosch, Stellenbosch 7600, South Africa \\ ${ }^{4}$ Department of Applied Biology and Chemistry, Tokyo University of Agriculture, 1-1-1 \\ Sakuragaoka, Setagaya, Tokyo 156-8502, Japan
}

\begin{abstract}
A taxonomic study was made of the genus Leuconostoc. The species in the genus were divided into three subclusters by phylogenetic analysis based on the 16S rRNA gene sequences. The three subclusters were the Leuconostoc mesenteroides subcluster (comprising $L$. carnosum, $L$. citreum, L. gasicomitatum, L. gelidum, L. inhae, L. kimchii, L. lactis, L. mesenteroides and $L$. pseudomesenteroides), the $L$. fructosum subcluster (L. durionis, $L$. ficulneum, $L$. fructosum and $L$. pseudoficulneum) and the L. fallax subcluster ( $L$. fallax). Phylogenetic trees based on the sequences of the 16S-23S rRNA gene intergenic spacer region, the $r p o C$ gene or the recA gene indicated a good correlation with the phylogenetic tree based on 16S rRNA gene sequences. The species in the $L$. fructosum subcluster were morphologically distinguishable from the species in the $L$. mesenteroides subcluster and $L$. fallax as species in the $L$. fructosum subcluster had rodshaped cells. In addition, the four species in the $L$. fructosum subcluster needed an electron acceptor for the dissimilation of D-glucose and produced acetic acid from D-glucose rather than ethanol. On the basis of evidence presented in this study, it is proposed that the four species in the L. fructosum subcluster, Leuconostoc durionis, Leuconostoc ficulneum, Leuconostoc fructosum and Leuconostoc pseudoficulneum, should be transferred to a novel genus, Fructobacillus gen. nov., as Fructobacillus durionis comb. nov. (type strain D-24 ${ }^{\top}=\mathrm{LMG}$ $22556^{\top}=$ CCUG $49949^{\top}$ ), Fructobacillus ficulneus comb. nov. (type strain $\mathrm{FS}-1^{\top}=\mathrm{DSM}$ $13613^{\top}=\mathrm{JCM} 12225^{\mathrm{T}}$ ), Fructobacillus fructosus comb. nov. (type strain IFO $3516^{\top}=\mathrm{DSM}$ $20349^{\top}=$ JCM $1119^{\top}=$ NRIC $1058^{\top}$ ) and Fructobacillus pseudoficulneus comb. nov. (type strain $\mathrm{LC}-51^{\top}=$ DSM $15468^{\top}=$ CECT $5759^{\top}$ ). The type species of the genus Fructobacillus is Fructobacillus fructosus gen. nov., comb. nov.. No significant physiological and biochemical differences were found between the species in the $L$. mesenteroides subcluster and $L$. fallax in the present study and thus $L$. fallax remains as a member of the genus Leuconostoc.
\end{abstract}

Abbreviations: ISR, intergenic spacer region; MLSA, multilocus sequence analysis; SEM, scanning electron microscope.

The GenBank/EMBL/DDBJ accession numbers for the sequences of the ISR and recA genes of $L$. carnosum NRIC $1722^{\top}, L$. citreum NRIC $1776{ }^{\top}, L$. gasicomitatum JCM $12535^{\top}$, L. gelidum NRIC $1778^{\top}$, L. inhae NRIC 0562 ${ }^{\top}$, L. lactis NRIC $1540^{\top}$, L. mesenteroides NRIC 1541 ${ }^{\top}$, L. pseudomesenteroides NRIC $1777^{\top}$, F. durionis LMG 22556 ${ }^{\top}$, F. ficulneus JCM $12225^{\top}$, F. fructosus NRIC $1058^{\top}$, F. pseudoficulneus DSM $15468^{\top}$ and L. fallax NRIC $0210^{\top}$ are AB290436-AB29448 and AB354939-AB354951, respectively. The GenBank/EMBL/DDBJ accession numbers for the sequences of the rpoC genes of $L$. inhae NRIC $0562^{\top}$, L. lactis NRIC $1540^{\top}$, F. durionis LMG $22556^{\top}$, L. gasicomitatum JCM $12535^{\top}$ and L. carnosum NRIC $1722^{\top}$ are AB354934AB354938, respectively.

Additional phylogenetic trees derived from 16S rRNA gene sequence analysis and constructed by using the maximum-likelihood and maximum-parsimony methods and growth curves in FYP, GYP and FGYP broth for the Leuconostoc species used in this study are available with the online version of this paper. 
The genus Leuconostoc was described by Van Tieghem (1878), and at the present time the genus consists of the following 14 species (excluding reclassified and synonymous species): Leuconostoc mesenteroides (type species), L. carnosum, $L$. citreum, $L$. durionis, $L$. fallax, $L$. ficulneum, $L$. fructosum, L. gasicomitatum, L. gelidum, L. inhae, $L$. kimchii, L. lactis, L. pseudoficulneum and L. pseudomesenteroides (Antunes et al., 2002; Björkroth et al., 2000, 2001; Chambel et al., 2006; Farrow et al., 1989; Garvie, 1960; Kim et al., 2000, 2003; Leisner et al., 2005; Martinez-Murcia \& Collins, 1991, 1992; Shaw \& Harding, 1989; Skerman et al., 1980; Van Tieghem, 1878). Leuconostoc argentinum was recently reclassified as a later synonym of $L$. lactis (Vancanneyt et al., 2006). Of the 14 species, L. durionis, L. fallax, L. ficulneum, L. fructosum and L. psuedoficulneum have been reported as atypical species in the genus Leuconostoc on the basis of their biochemical characteristics and/or phylogenetic position as determined by $16 \mathrm{~S}$ rRNA gene sequence analysis (Antunes et al., 2002; Chambel et al., 2006; Leisner et al., 2005; Martinez-Murcia \& Collins, 1991). Moreover, cells of $L$. durionis, L. ficulneum and $L$. fructosum have been reported to be rod-shaped (Antunes et al., 2002; Leisner et al., 2005) and the morphological characteristics of these species disagreed with those of members of the genus Leuconostoc sensu strictu, which were coccoid or elongated (Dellaglio et al., 1995). Therefore, the genus Leuconostoc is considered to be heterogeneous and a taxonomic re-evaluation is needed. This work reports the results of a taxonomic study of the species in the genus Leuconostoc and concludes that the genus Leuconostoc should be divided into two genera.

The type strains of 13 of the species in the genus Leuconostoc were used in the present study (Table 1). The type strain of L. kimchii could not be obtained from any culture collection or from co-authors due to a patent which covers the strain. The strains used in this study were obtained from the NODAI Culture Collection Center, Tokyo University of Agriculture, Tokyo, and the JCM, DSMZ and LMG culture collections. The culture broths and temperatures used for culturing the type strains are listed in Table 1. GYP broth was composed of $\left(1^{-1}\right)$ : $20 \mathrm{~g}$ D-glucose, $10 \mathrm{~g}$ yeast extract, 5 g polypeptone, $2 \mathrm{~g}$ sodium acetate, $0.5 \mathrm{~g}$ Tween $80,0.2 \mathrm{~g}$ $\mathrm{MgSO}_{4} \cdot 7 \mathrm{H}_{2} \mathrm{O}, 0.01 \mathrm{~g} \mathrm{MnSO}_{4} \cdot 4 \mathrm{H}_{2} \mathrm{O}, 0.01 \mathrm{~g} \mathrm{FeSO}_{4} \cdot 7 \mathrm{H}_{2} \mathrm{O}$ and $0.01 \mathrm{~g} \mathrm{NaCl}$, at pH 6.8. FYP broth was composed of GYP broth in which $20 \mathrm{~g}$ D-glucose $\left(1^{-1}\right)$ was replaced with $20 \mathrm{~g}$ D-fructose $\left(1^{-1}\right)$.

To determine the phylogenetic relationships among the species of the genus Leuconostoc, the sequences of the $16 \mathrm{~S}$ rRNA gene and the 16S-23S rRNA gene intergenic spacer region (ISR) were analysed. In addition, multilocus sequence analysis (MLSA) using two housekeeping genes was applied. MLSA was recently used for the classification of lactic acid bacteria and related taxa (Jian \& Dong, 2002; Naser et al., 2005, 2006).

For the phylogenetic analysis based on 16S rRNA gene sequences, the sequences of the type strains of the species in the genus Leuconostoc and related taxa were retrieved from the DDBJ database. Multiple alignments of the sequences were performed with the CLUSTAL_X program version 1.18 (Thompson et al., 1997). Distance matrices for the aligned sequences were calculated by using Kimura's two-parameter method (Kimura, 1980). The neighbour-joining method was used to construct a phylogenetic tree (Saitou \& Nei, 1987). The robustness of individual branches was estimated by using bootstrapping with 1000 replicates (Felsenstein, 1985). Phylogenetic trees were also constructed by using the maximum-likelihood (CavalliSforza \& Edwards, 1967) and maximum-parsimony (Kluge \& Farris, 1969) methods with PHYLIP version 3.65 (Felsenstein, 2005). Lactococcus lactis was used as an outgroup. Approximately $1430 \mathrm{bp}$ of the $16 \mathrm{~S}$ rRNA gene sequences of the tested strains were used to construct phylogenetic trees.

The phylogenetic tree constructed with the neighbourjoining method revealed that the genus Leuconostoc was

Table 1. Bacterial strains used in the present study

\begin{tabular}{|c|c|c|c|c|}
\hline Species & Type strain & Revised nomenclature & Culture medium & Temperature $\left({ }^{\circ} \mathrm{C}\right)$ \\
\hline L. carnosum & NRIC $1722^{\mathrm{T}}$ & L. carnosum & GYP & 30 \\
\hline L. citreum & NRIC $1776^{\mathrm{T}}$ & L. citreum & GYP & 30 \\
\hline L. durionis & LMG $22556^{\mathrm{T}}$ & Fructobacillus durionis comb. nov. & FYP & 30 \\
\hline L. fallax & NRIC $0210^{\mathrm{T}}$ & L. fallax & GYP & 30 \\
\hline L. ficulneum & JCM $12225^{\mathrm{T}}$ & Fructobacillus ficulneus comb. nov. & FYP & 30 \\
\hline L. fructosum & NRIC $1058^{\mathrm{T}}$ & Fructobacillus fructosus comb. nov. & FYP & 30 \\
\hline L. gasicomitatum & JCM $12535^{\mathrm{T}}$ & L. gasicomitatum & GYP & 25 \\
\hline L. gelidum & NRIC $1778^{\mathrm{T}}$ & L. gelidum & GYP & 25 \\
\hline L. inhae & NRIC $0562^{\mathrm{T}}$ & L. inhae & GYP & 25 \\
\hline L. lactis & NRIC $1540^{\mathrm{T}}$ & L. lactis & GYP & 30 \\
\hline L. mesenteroides & NRIC $1541^{\mathrm{T}}$ & L. mesenteroides & GYP & 30 \\
\hline L. pseudoficulneum & DSM $15468^{\mathrm{T}}$ & $\begin{array}{l}\text { Fructobacillus pseudoficulneus comb. } \\
\text { nov. }\end{array}$ & FYP & 30 \\
\hline L. pseudomesenteroides & NRIC $1777^{\mathrm{T}}$ & L. pseudomesenteroides & GYP & 30 \\
\hline
\end{tabular}


divided into three subclusters; the $L$. mesenteroides subcluster (comprising L. carnosum, L. citreum, L. gasicomitatum, L. gelidum, L. inhae, L. kimchii, L. lactis, $L$. mesenteroides and L. pseudomesenteroides), the L. fructosum subcluster (comprising $L$. durionis, $L$. ficulneum, $L$. fructosum and L. pseudoficulneum) and the L. fallax subcluster (L. fallax) (Fig. 1). Identical tree topologies were obtained from the phylogenetic trees constructed by using maximum-likelihood and maximum-parsimony methods (see Supplementary Figs S1 and S2 in IJSEM Online). When the sequences of the type strains were aligned by using CLUSTAL_X, it was apparent that L. fallax was genetically distinct from the other Leuconostoc species based on the sequence of the V1 region of the 16S rRNA gene. The $\mathrm{V} 1$ region was based on the secondary structure model of SSU rRNA described by Van de Peer et al. (2000). The sequence of the V1 region of $L$. fallax had large gaps (approx. $16 \mathrm{bp)} \mathrm{compared} \mathrm{with} \mathrm{those} \mathrm{of} \mathrm{other} \mathrm{Leuconostoc}$ species and was similar to those of species of the genera Weissella and Oenococcus (data not shown). The differences between L. fallax and other species of the genus Leuconostoc may be due to differences in the secondary structure of the $\mathrm{V} 1$ region of the $16 \mathrm{~S}$ rRNA gene. The gene sequence similarities of the species within the $L$. mesenteroides subcluster ranged from 97.1 to $99.5 \%$. Species in the $L$. mesenteroides subcluster had gene sequence similarities of $91.0-94.4 \%$ and $91.1-93.1 \%$ with species of the $L$. fructosum subcluster and L. fallax subcluster, respectively. The sequence similarities of the species within the $L$. fructosum subcluster ranged from 94.2 to $98.0 \%$ and showed $90.4-91.7 \%$ sequence similarity with $L$. fallax. Recently, the genera Pilibacter and Paralactobacillus were described as novel genera of lactic acid bacteria (Higashiguchi et al., 2006; Leisner et al., 2000). The sequence similarity between the genus Pilibacter and the closest phylogenetic relative, the genus Enterococcus, was less than $92.8 \%$ (Higashiguchi et al., 2006) and that between the genus Paralactobacillus and the closest phylogenetic relatives, species in the Lactobacillus casei group (Collins et al., 1991), was less than $91.7 \%$ (Leisner et al., 2000). These values are close to the sequence similarities found among the three subclusters of the genus Leuconostoc mentioned above.

For the determination of ISR sequences of the type strains of the Leuconostoc species, amplification of the ISR was performed by using primers 16S/p2 (5'-CTTGTACACACCGCCCGTC) and 23S/p7 (5'-GGTACTTAGATGTTTCAGTTC) as described by Rachman et al. (2003). The primers $16 \mathrm{~S} / \mathrm{p} 2$ and $23 \mathrm{~S} / \mathrm{p} 7$ anneal at positions 1388-1406 of the 16S rRNA gene and at positions 207-189 of the 23S rRNA gene; position numbers were based on the Escherichia coli numbering system (GenBank accession no. V00348; Brosius et al., 1981). An amplification product of approximately $750 \mathrm{bp}$ was obtained for each of the strains (data not shown). Purification and sequencing of the product were performed as described previously (Endo \& Okada, 2005). After sequencing, the

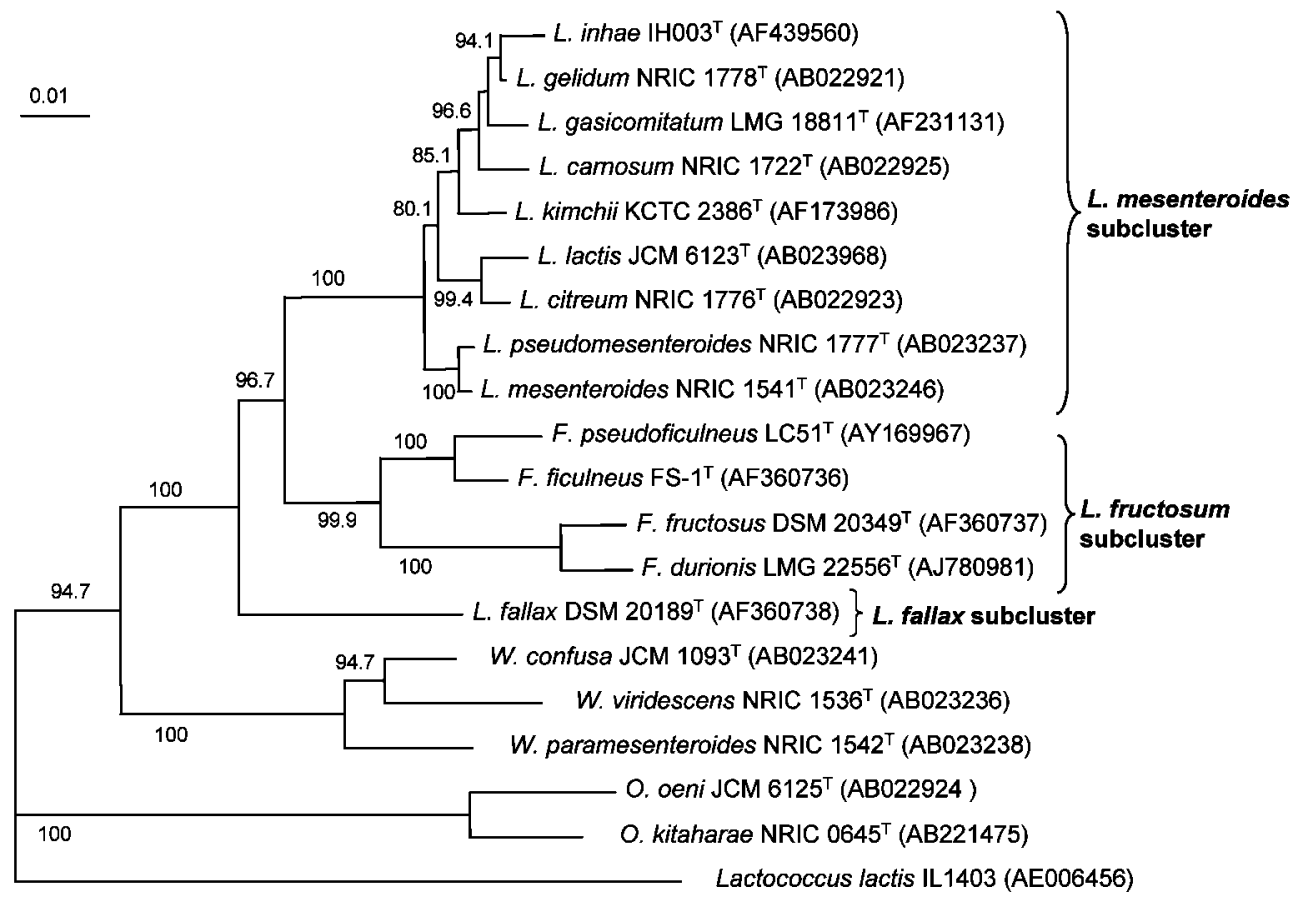

Fig. 1. Phylogenetic relationships of the genera Leuconostoc, Fructobacillus gen. nov. and related taxa based on $16 \mathrm{~S}$ rRNA gene sequences. The tree was constructed by the neighbour-joining method. Lactococcus lactis was used as an outgroup. Bootstrap values are given at branching points; values above $70 \%$ are indicated. Bar, $0.01 \mathrm{~K}_{\text {nuc }}$. 
sequences of the 16S rRNA gene and the 23S rRNA gene attached to the ISR were deleted and only the sequences of the ISR were used for the phylogenetic analysis. Phylogenetic analysis was performed as described above and a phylogenetic tree was constructed according to the neighbour-joining method. Oenococcus oeni was used as an outgroup. Species of the genus Weissella were not used in this study as they possessed different length ISRs in each chromosomal DNA (Zavaleta et al., 1996).

The phylogenetic tree based on ISR sequences showed that the genus Leuconostoc was divided into three ISRsubclusters (Fig. 2). The L. mesenteroides ISR-subcluster consisted of eight species (L. carnosum, L. citreum, $L$. gasicomitatum, L. gelidum, L. inhae, L. lactis, L. mesenteroides and L. pseudomesenteroides), the L. fructosum ISRsubcluster consisted of four species ( $L$. durionis, $L$. ficulneum, L. fructosum and L. pseudoficulneum) and the L. fallax ISR-subcluster consisted of only L. fallax (Fig. 2). The ISR-subclusters correlated well with the subclusters based on the 16S rRNA gene sequences (Fig. 1). The sequence similarities of the species within the $L$. mesenteroides ISR-subcluster ranged from 80.2 to $99.5 \%$. Species in the $L$. mesenteroides ISR-subcluster showed $69.2-80.1 \%$ and $73.7-83.6 \%$ to the species in the L. fructosum ISRsubcluster and $L$. fallax, respectively. Sequence similarities of the species within the L. fructosum ISR-subcluster ranged from 81.3 to $92.4 \%$. Species in the $L$. fructosum ISR- subcluster showed $71.1-73.1 \%$ sequence similarity to $L$. fallax.

The rpoC gene, encoding the $\beta^{\prime}$ subunit of the DNAdependent RNA polymerase, and the recA gene, encoding a recombinase A protein, were used for MLSA in this study. Recombinase $\mathrm{A}$ is a protein implicated in homologous DNA recombination, SOS induction and DNA damageinduced mutagenesis (Eisen, 1995). These two genes have often been used previously as markers for phylogenetic analysis and for the differentiation of lactic acid bacteria (Chelo et al., 2007; Felis et al., 2001; Morse et al., 1996; Torriani et al., 2001). Partial rpoC gene sequences were determined for the type strains of $L$. carnosum, L. durionis, L. gasicomitatum, L. inhae and L. lactis and partial recA gene sequences were determined for the type strains of the genus Leuconostoc listed in Table 1. The sequences of both genes from related taxa and those of the $r p o C$ gene for other Leuconostoc species were retrieved from the DDBJ database. Partial $r p o C$ genes of the tested strains were amplified by the method described by Morse et al. (1996), but the rpoC1053R primer (CAAGAAAGGSCCAACATCRATAAC; Chelo et al., 2007) was used as a reverse primer. An amplification of the $r e c A$ genes was performed according to the method described by Dellaglio et al. (2005). Purification and sequencing of the amplification products were carried out as described previously (Endo \& Okada, 2005). Phylogenetic analysis was conducted as

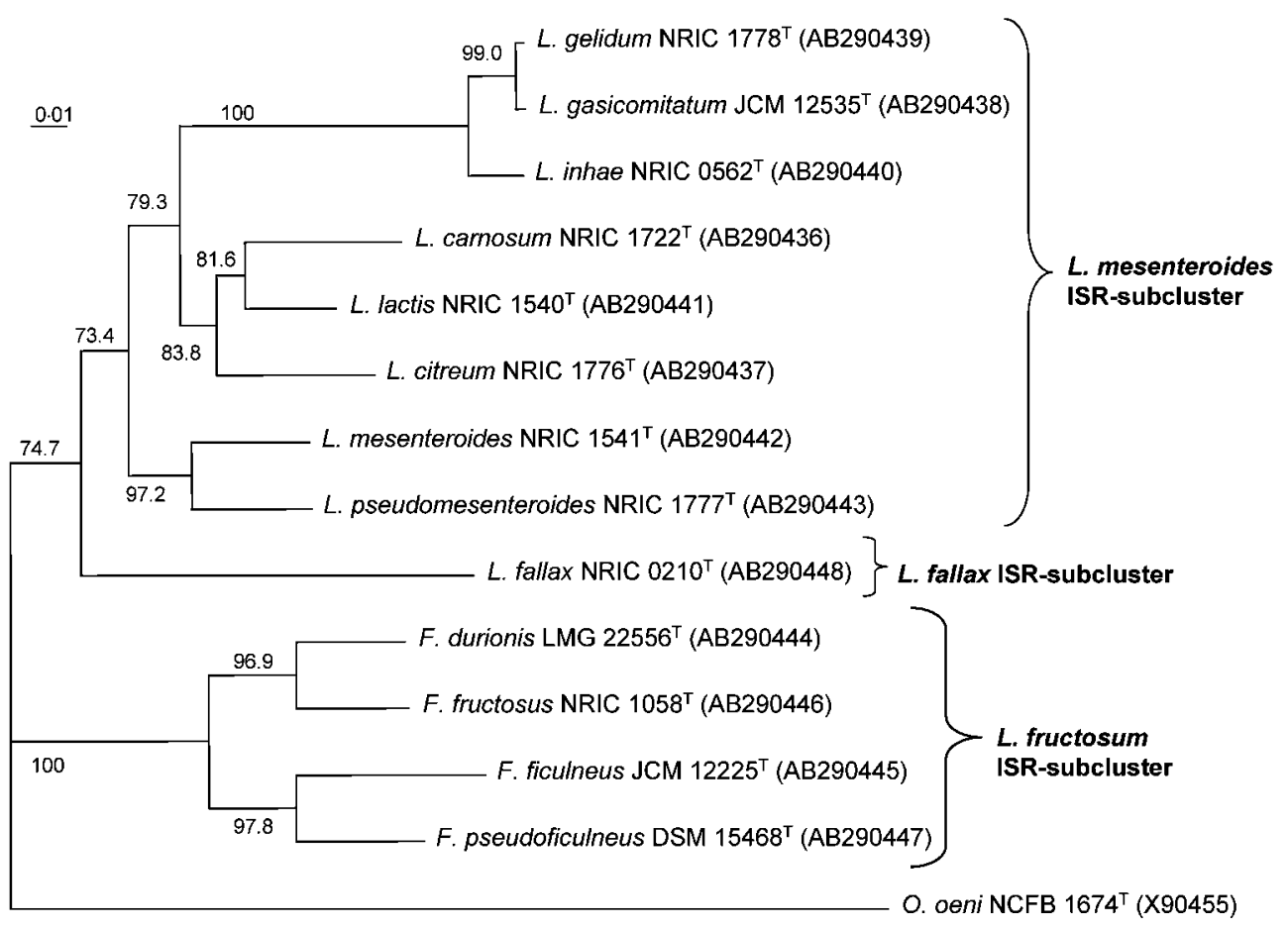

Fig. 2. Phylogenetic relationships of the genera Leuconostoc and Fructobacillus gen. nov. based on the sequences of the 16S-23S rRNA gene ISR. The tree was constructed by the neighbour-joining method. Oenococcus oeni was used as an outgroup. Bootstrap values are given at branching points; values above $70 \%$ are indicated. Bar, $0.01 K_{\text {nuc }}$. 
described above and phylogenetic trees were constructed by the neighbour-joining method. Lactococcus lactis was used as an outgroup.

The phylogenetic tree based on the rpoC gene sequences revealed that the genus Leuconostoc produced three subclusters: the $L$. mesenteroides $r p o C$-subcluster, the $L$. fructosum rpoC-subcluster and the L. fallax rpoC-subcluster (Fig. 3). The three rpoC-subclusters showed a good correlation with the subclusters identified on the basis of the 16S rRNA gene or the ISR sequences (Figs 1 and 2). The L. fructosum rpoC-subcluster was related to the Weissella rpoC-cluster and L. fallax was distantly positioned with regard to all of the species used in this study (Fig. 3). Based on the recA gene sequences, the genus Leuconostoc was divided into two subclusters: the $L$. mesenteroides recA-subcluster and the L. fructosum recAsubcluster (Fig. 4). Unlike the other phylogenetic trees (Figs 1,2 and 3), L. fallax was located inside the $L$. mesenteroides recA-subcluster (Fig. 4). The different phylogenetic positions of L. fallax among the three phylogenetic trees may be due to the fact that it had no phylogenetic neighbours (Fig. 1).

In our phylogenetic analysis, three of the four phylogenetic trees, based on the sequences of the 16S rRNA gene, ISR, rpoC gene or recA gene, confirmed the formation of three subclusters in the genus Leuconostoc with a good correlation and high bootstrap values. Thus, we conclude that the genus Leuconostoc is phylogenetically divided into three groups: the $L$. mesenteroides group (comprising $L$. carnosum, L. citreum, L. gasicomitatum, L. gelidum, L. inhae, L. kimchii, $L$. lactis, $L$. mesenteroides and $L$. pseudomesenteroides), the L. fructosum group (comprising L. durionis, L. ficulneum, L. fructosum and L. pseudoficulneum) and the L. fallax group (L. fallax). This finding correlated well with the MLSA data obtained by using four housekeeping genes of three genera of the Leuconostoc group, Leuconostoc, Oenococcus and Weissella, as determined by Chelo et al. (2007). Disagreements have often been found between phylogenetic analyses based on housekeeping genes and the 16S rRNA gene (Naser et al., 2005; Chelo et al., 2007).

The morphological characteristics of the Leuconostoc type strains were determined by using a scanning electron microscope (SEM). The strains were cultured for 1-2 days under the conditions shown in Table 1. After culture, cells were washed with $0.2 \mathrm{M}$ phosphate buffer ( $\mathrm{pH} 7.0$ ), fixed with $2 \%$ glutaraldehyde for $2 \mathrm{~h}$ at $4{ }^{\circ} \mathrm{C}$, post-fixed with $1 \% \mathrm{OsO}_{4}$ for $3 \mathrm{~h}$ at $4{ }^{\circ} \mathrm{C}$, dehydrated with a series of increasing ethanol concentrations $(70 \%, 80 \%, 90 \%, 95 \%$ and twice at $100 \%$ for $15 \mathrm{~min}$ each) and soaked in 3methylbutyl acetate for 1 day. The prepared cells were subsequently critical-point dried in a drying unit (model HCP-2; Hitachi), sputtered with Pt/Pd (model E-102;

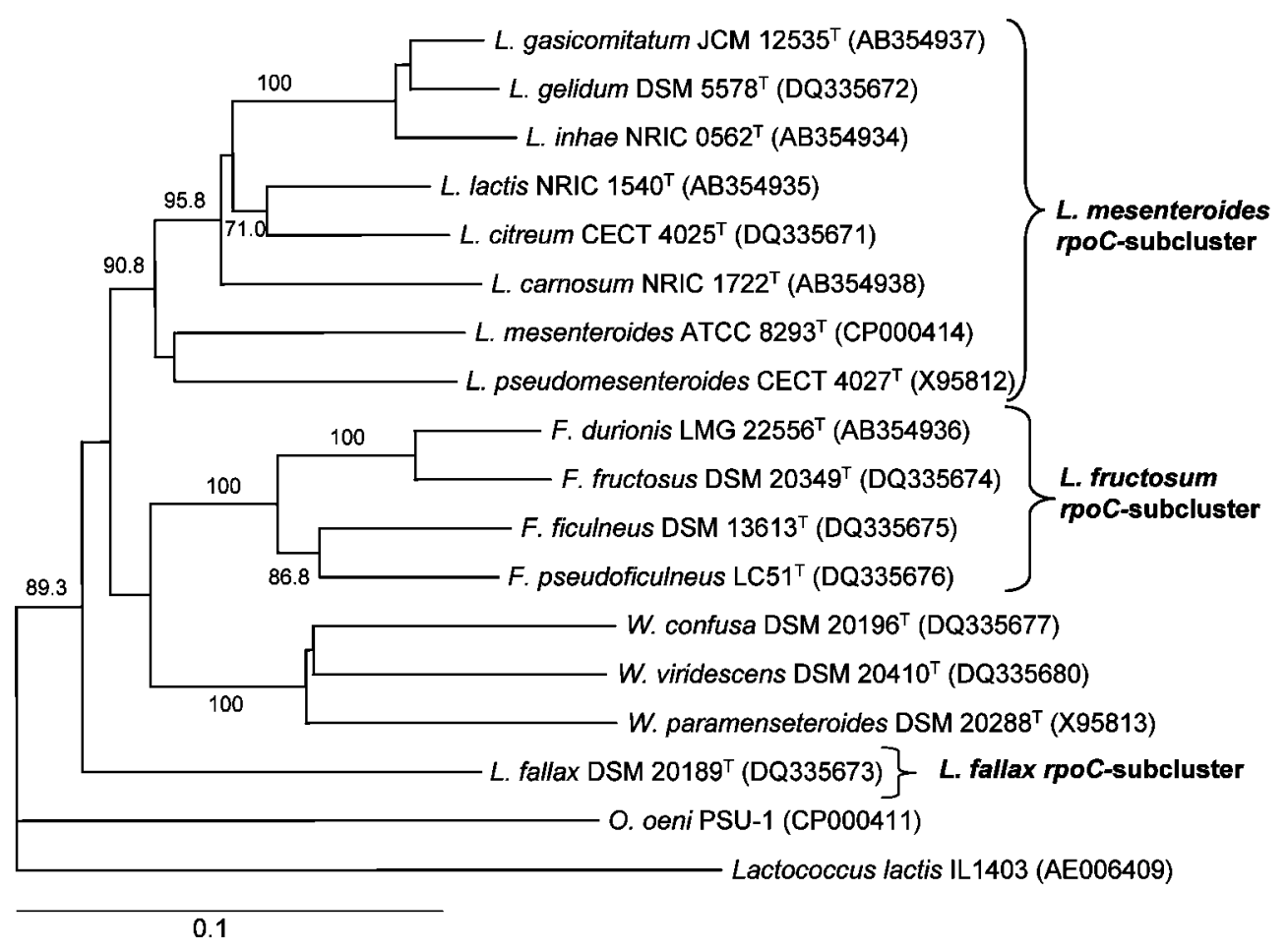

Fig. 3. Phylogenetic relationships of the genera Leuconostoc, Fructobacillus gen. nov. and related taxa based on the rpoC gene sequences. Lactococcus lactis was used as an outgroup. Bootstrap values are given at branching points; values above $70 \%$ are indicated. Bar, $0.1 K_{\text {nuc }}$. 


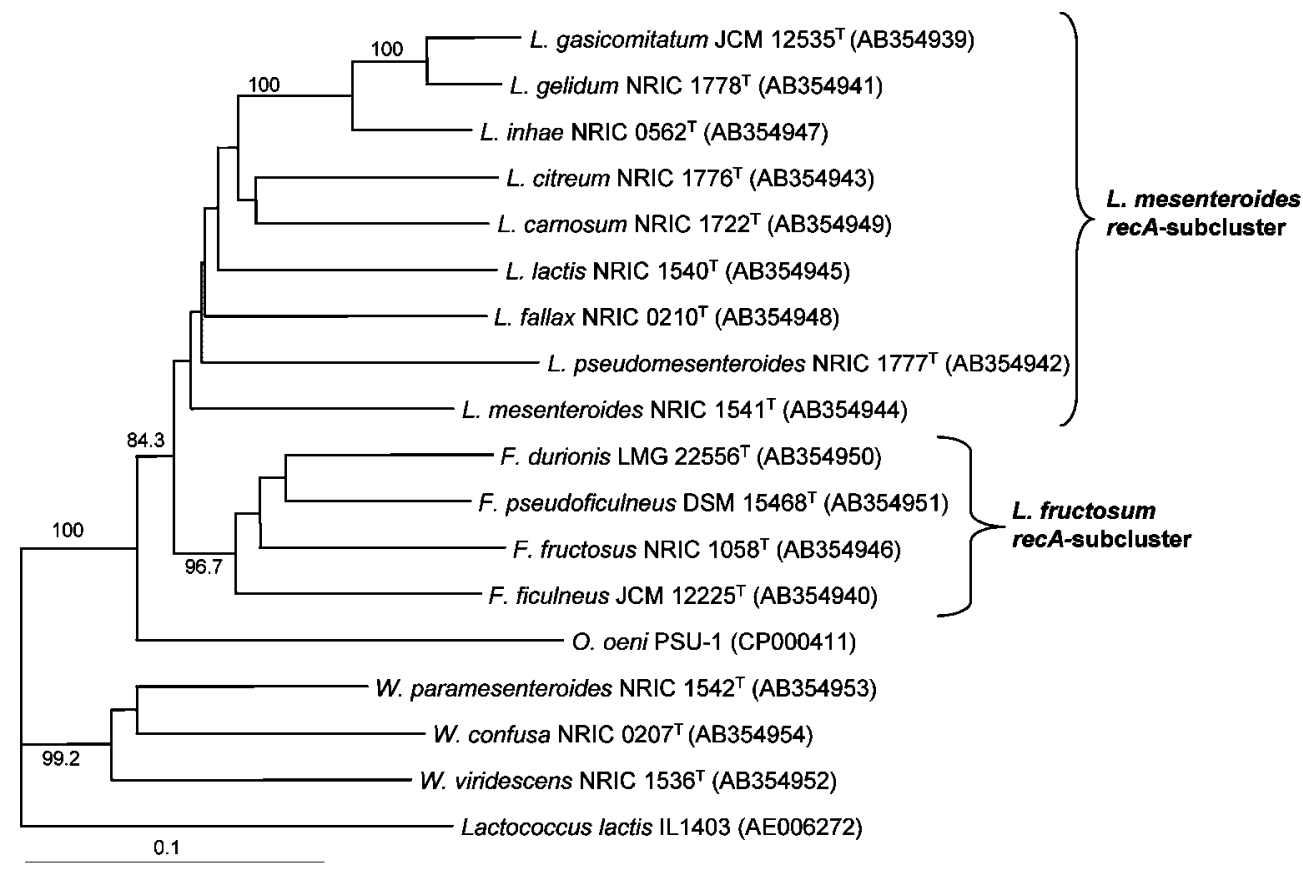

Fig. 4. Phylogenetic relationships of the genera Leuconostoc, Fructobacillus gen. nov. and related taxa based on recA gene sequences. Lactococcus lactis was used as an outgroup. Bootstrap values are given at branching points; values above $70 \%$ are indicated. Bar, $0.1 K_{\text {nuc. }}$

Hitachi), and observed with a SEM (model S-4000; Hitachi). The SEM observations revealed various morphological characteristics for the strains examined. Cells of $L$. carnosum, L. citreum, L. gasicomitatum, L. gelidum, $L$. inhae, L. lactis, L. mesenteroides and L. pseudomesenteroides, the species of the L. mesenteroides subcluster (Figs 1, 2, 3 and 4), were spherical, oval or coccobacillary (data not shown) and the cell shape was consistent with that previously given for the genus Leuconostoc (Sneath et al., 1986). However, cells of $L$. durionis, L. ficulneum, $L$. fructosum and $L$. pseudoficulneum, the species of the $L$. fructosum subcluster (Figs 1, 2, 3 and 4), were rod-shaped (Fig. 5) and resembled species of the genus Lactobacillus. This observation disagreed with the morphological characteristics of the genus Leuconostoc as described previously (Sneath et al., 1986). L. fructosum was formerly classified as Lactobacillus fructosus (Kodama, 1956) and was reclassified as L. fructosum by Antunes et al. (2002). Therefore, cells of $L$. fructosum were known to be rod-shaped. Cells of $L$. durionis and L. ficulneum have also been reported to be rod-shaped (Antunes et al., 2002; Leisner et al., 2005). Cells of $L$. pseudoficulneum were previously reported to be ovoid (Chambel et al., 2006), but our SEM observations clearly indicated that L. pseudoficulneum had rod-shaped cells. Six strains of $L$. pseudoficulneum were originally isolated from a ripe fig (Chambel et al., 2006) and so we determined the morphological characteristics of these additional strains, LC47, LC 48, LC 49, LC 50 and LC 52, which were provided by $\mathrm{Dr}$ Rogério Tenreiro (Universidade de
Lisboa). Our microscopic observations confirmed that these five additional strains of L. pseudoficulneum had rodshaped cells rather than ovoid cells, and it is not clear why the cells were originally described as ovoid by Chambel et al. (2006). L. fallax had spherical cells (Fig. 5) and coccobacillary cells were not detected.

Biochemical and physiological characteristics such as acid production from carbohydrates, growth in a broth containing D-glucose and/or fructose as substrate(s), organic acids, ethanol produced from D-glucose and sugar tolerance were determined for the Leuconostoc type strains. Acid production from carbohydrates was determined by a previously described method (Endo \& Okada, 2005). The data are presented in Table 2. All the strains produced acid from $\mathrm{D}$-glucose and D-fructose, but the type strain of $L$. lactis did not produce acid from D-fructose. Interestingly, the type strains of $L$. durionis, L. ficulneum, L. fructosum and L. pseudoficulneum produced acid from only a limited number of carbohydrates, two for $L$. ficulneum, $L$. fructosum and L. pseudoficulneum, and three for $L$. durionis. This number of carbohydrates was much less than that found for the type strains of other Leuconostoc species (Table 2). The type strains of L. ficulneum, L. fructosum and L. pseudoficulneum and L. durionis produced acid from Dglucose and D-fructose and showed a delayed reaction for D-mannitol.

Growth in GYP broth, FYP broth and FGYP broth was studied for the determination of the most suitable growth 

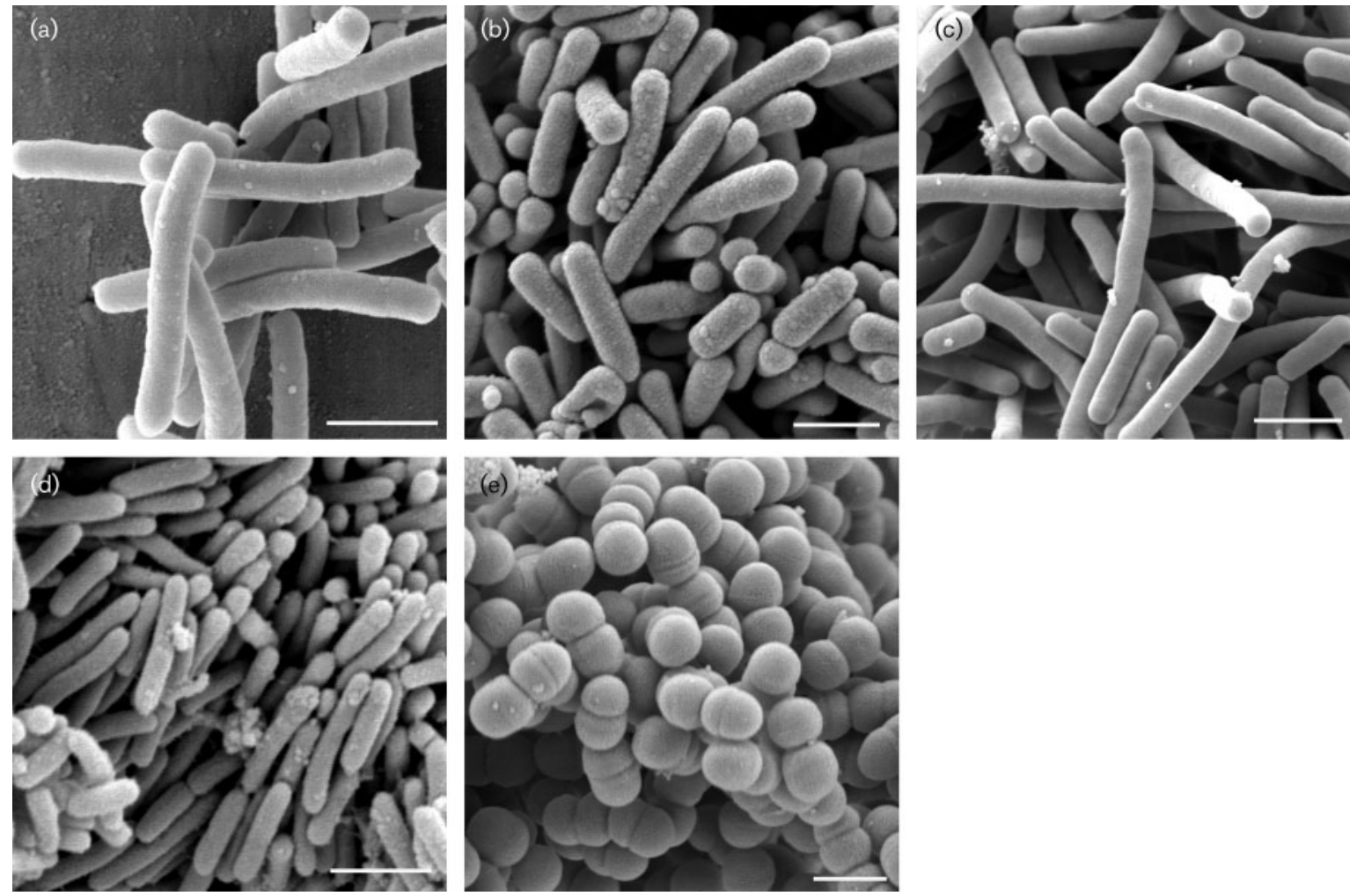

Fig. 5. Scanning electron micrographs of $F$. durionis LMG $22556^{\top}$ (a), F. ficulneus JCM $12225^{\top}$ (b), F. fructosus NRIC $1058^{\top}$ (c), F. pseudoficulneus DSM $15468^{\top}$ (d) and L. fallax NRIC $0210^{\top}$ (e). Bars, $1 \mu \mathrm{m}$.

Table 2. Acid production from carbohydrates of the type strains of the species in the genera Leuconostoc and Fructobacillus gen. nov.

Taxa: 1, L. carnosum; 2, L. citreum; 3, L. gasicomitatum; 4, L. gelidum; 5, L. inhae; 6, L. lactis; 7, L. mesenteroides; 8, L. pseudomesenteroides; 9, Fructobacillus durionis; 10, Fructobacillus ficulneus; 11, Fructobacillus fructosus; 12, Fructobacillus pseudoficulneus; 13, L. fallax. +, Positive; -, negative; D, delay. All values are for the type strains of the species. All strains showed a positive reaction for D-glucose, but were negative for Drhamnose, D-melezitose, D-sorbitol and starch.

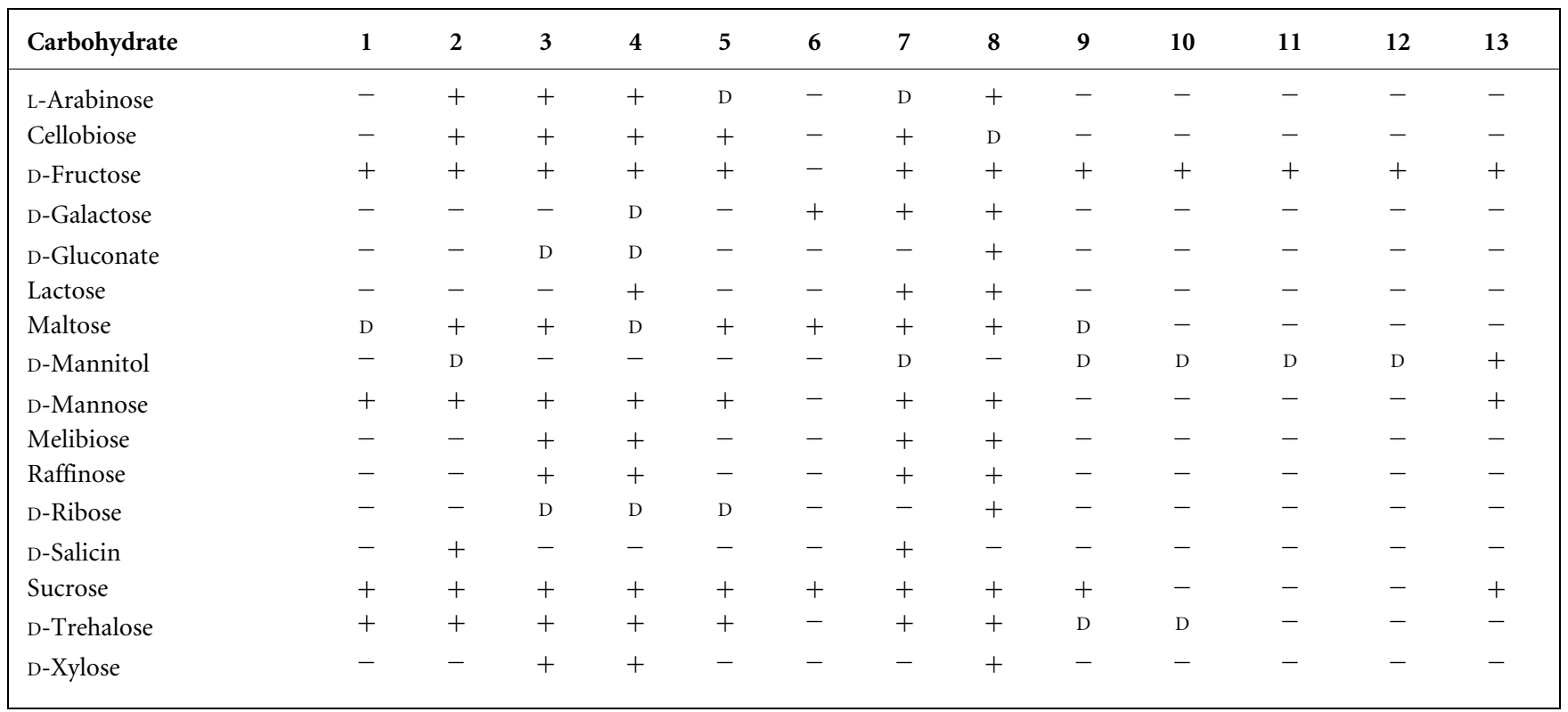


substrate for the Leuconostoc type strains. FGYP broth was based on GYP broth and contained $10 \mathrm{~g}$ D-glucose $\mathrm{l}^{-1}$ and $10 \mathrm{~g}$ D-fructose $1^{-1}$ as the growth substrates. Each strain was pre-cultured under the conditions described in Table 1. Cells were washed twice with saline, washed cells were diluted 100-fold with saline and the dilutions were inoculated in the GYP, FYP and FGYP broths. The broths were cultured for 5 days at the temperatures given in Table 1. Growth was monitored by optical density at $660 \mathrm{~nm}$ with a spectrophotometer (NovaspecII; Biochrom Ltd). The type strains of L. carnosum, L. citreum, L. gasicomitatum, L. gelidum, L. inhae, L. lactis, L. mesenteroides, $L$. pseudomesenteroides and L. fallax grew well in the three broths (see Supplementary Figs S3a, S3b and S3c in IJSEM Online), but the type strain of L. lactis did not grow in FYP broth (Supplementary Fig. S3b). The reason that the type strain of $L$. lactis did not grow in FYP broth was due to a deficiency in D-fructose dissimilation (Table 2). In contrast, the type strains of $L$. durionis, L. ficulneum, $L$. fructosum and L. pseudoficulneum all grew well in the FYP and FGYP broths (Supplementary Figs S3b, S3c), but they grew poorly in GYP broth (Supplementary Fig. S3a). DGlucose is the most common substrate for the cultivation of lactic acid bacteria and thus the poor growth in GYP broth and good growth in FYP broth of the type strains of $L$. durionis, L. ficulneum, $L$. fructosum and $L$. pseudoficulneum is unusual. Interestingly, these four species were originally isolated from fruits, flowers or a fermented food derived from fruit (Antunes et al., 2002; Chambel et al., 2006; Kodama, 1956; Leisner et al., 2005) which may have contained large amounts of D-fructose. This could suggest that these four species have become adapted to survive in such environments. Thus, the isolation of lactic acid bacteria from fructose-rich environments, such as flowers, fruits or their related products, should be performed by using D-glucose and D-fructose as growth substrates. It was reported by Leisner et al. (2005) that $L$. durionis and $L$. fructosum produced large amounts of D-mannitol when Dglucose and D-fructose were used as growth substrates. We obtained similar results from the type strains of $L$. durionis, L. ficulneum, L. fructosum and L. pseudoficulneum (data not shown). This may indicate that these four strains need an electron acceptor for growth and are able to utilize Dfructose as an electron acceptor for dissimilation of Dglucose in FGYP broth. In fact, these four strains grew poorly in GYP broth but grew well in GYP broth containing $10 \mathrm{~g}$ pyruvate $\mathrm{l}^{-1}$ as an electron acceptor (data not shown). In addition, the growth of these four type strains in GYP broth was enhanced by aerobic culturing, and the aerobic growth in GYP broth was comparable with growth in FYP broth as shown in Supplementary Fig. S3b. The surface growth of these four strains on GYP agar was also enhanced under aerobic conditions compared with growth under anaerobic conditions [anaerobic jars (GasPak System, BBL); data not shown]. This may indicate that these four type strains can also use atmospheric $\mathrm{O}_{2}$ as an electron acceptor. Sakamoto \& Komagata (1996) demonstrated that some strains of the genus Lactobacillus and
Pediococcus acidilactici and L. mesenteroides grew better under aerobic conditions than under anaerobic conditions.

The amounts of organic acids and ethanol produced from D-glucose in GYP broth under stationary conditions were determined for the Leuconostoc type strains by using a HPLC (Alliance PDA System; Waters) or the F-kit ethanol (Roche Diagnostics). The type strains of $L$. carnosum, $L$. citreum, L. gasicomitatum, L. gelidum, L. inhae, L. lactis, $L$. mesenteroides, L. pseudomesenteroides and L. fallax produced equimolar amounts of lactic acid and ethanol and trace amounts of acetic acid from D-glucose and this was consistent with the characteristics of the genus Leuconostoc as described previously (Dellaglio et al., 1995). In contrast, the type strains of $L$. durionis, L. ficulneum, L. fructosum and L. pseudoficulneum produced equimolar amounts of lactic acid and acetic acid but ethanol was not detected. The production of equimolar amounts of acids produced from D-glucose under stationary conditions has not previously been reported for any lactic acid bacteria, including the species in the genus Leuconostoc. Generally, species of the genus Leuconostoc metabolize D-glucose via a combination of the hexose monophosphate pathway and the pentose phosphate pathway (Dellaglio et al., 1995; DeMoss et al., 1951; Sneath et al., 1986), and ethanol is produced by a reduction of acetyl-phosphate via acetylCoA and acetaldehyde. However, our results suggest that $L$. durionis, L. ficulneum, L. fructosum and L. pseudoficulneum convert acetyl-phosphate to acetic acid and not to acetylCoA. On this pathway, the oxidation of NADPH is not sufficient for NADP/NADPH cycling, as Leuconostoc species usually oxidize NADPH to NADP by lactate dehydrogenase, acetaldehyde dehydrogenase and alcohol dehydrogenase (Condon, 1987). Consequently, if the type strains of $L$. durionis, $L$. ficulneum, $L$. fructosum and $L$. pseudoficulneum produce acetic acid by this pathway, an additional electron acceptor is needed for the oxidation of NADPH. This finding correlated well with the results of the requirement for electron acceptors, such as pyruvate and $\mathrm{O}_{2}$, on D-glucose dissimilation for L. durionis, L. ficulneum, L. fructosum and L. pseudoficulneum. In this pathway, it is well known that twice the amount of ATP is produced as compared to the reduction pathway of acetyl-phosphate to ethanol (Johnson \& McCleskey, 1957) and species of the genus Leuconostoc usually use this pathway under aerobic conditions (Condon, 1987; Dellaglio et al., 1995; Keenan, 1968; Lucey \& Condon, 1986).

Sugar tolerance was determined by the growth of the type strains in a broth containing $2 \%, 10 \%, 20 \%, 30 \%, 40 \%$ or $50 \%(\mathrm{w} / \mathrm{v})$ substrate. D-Glucose was used as the substrate for the type strains of $L$. carnosum, L. citreum, L. gasicomitatum, L. gelidum, L. inhae, L. lactis, $L$. mesenteroides, L. pseudomesenteroides and L. fallax, and Dfructose was used for the type strains of $L$. durionis, $L$. ficulneum, $L$. fructosum and $L$. pseudoficulneum. Most strains tested grew on concentrations of $30 \%$ substrate, and the type strains of $L$. durionis, L. fallax, L. ficulneum, $L$. fructosum, L. pseudoficulneum and L. pseudomesenteroides 
were able to grow on $40 \%$ substrate. Furthermore, the type strains of $L$. durionis, $L$. ficulneum, $L$. fructosum and $L$. pseudoficulneum grew poorly on a $50 \%$ substrate. The data indicated that these four species are xerotolerant bacteria. Antunes et al. (2002) obtained similar results for $L$. ficulneum and $L$. fructosum. The type strains of $L$. durionis, L. ficulneum, L. fructosum and L. pseudoficulneum had moderate tolerance to $\mathrm{NaCl}$, and these four strains grew well on $5 \%(\mathrm{w} / \mathrm{v}) \mathrm{NaCl}$, but poorly on $7.5 \% \mathrm{NaCl}$.

Antunes et al. (2002) mentioned that L. ficulneum, $L$. fructosum and $L$. fallax could be assigned to novel genera by phylogenetic analysis based on the 16S rRNA gene sequences, but there were no noteworthy biochemical or physiological differences to distinguish these three species from the other species of the genus Leuconostoc. Our phylogenetic trees confirmed the division of the genus Leuconostoc into three groups, the L. mesenteroides group, the $L$. fructosum group and $L$. fallax. In addition, the species in the $L$. fructosum group, $L$. durionis, $L$. ficulneum, $L$. fructosum and L. pseudoficulneum, were clearly distinguished from the other species of the genus Leuconostoc by morphological and biochemical characteristics. Cell morphology and the inability to produce ethanol from D-glucose were key features that enabled the separation of these four species from the genus Leuconostoc. These four species also needed an electron acceptor for D-glucose dissimilation. These are noteworthy differential characteristics for the reclassification of the genus Leuconostoc as compared with the genera of lactic acid bacteria described recently. The genera Pilibacter and Paralactobacillus were established recently as novel genera of lactic acid bacteria by the differentiation of biochemical and morphological characteristics or their phylogenetic position as compared with the genera Enterococcus and Lactobacillus (Higashiguchi et al., 2006; Leisner et al., 2000). Therefore it is proposed that the species Leuconostoc durionis, Leuconostoc ficulneum, Leuconostoc fructosum and Leuconostoc pseudoficulneum should be transferred to a novel genus, Fructobacillus gen. nov., as Fructobacillus durionis comb. nov., Fructobacillus ficulneus comb. nov., Fructobacillus fructosus comb. nov. and Fructobacillus pseudoficulneus comb. nov. The type species of the genus Fructobacillus is F. fructosus.

$L$. fallax was distinguished from $L$. durionis, L. ficulneum, $L$. fructosum and L. pseudoficulneum and the other species of the genus Leuconostoc as determined by on phylogenetic analysis based on the sequences of the 16S rRNA gene, the ISR and two housekeeping genes, but not the recA gene. However, no noteworthy physiological and biochemical differences were found between $L$. fallax and the other species of the genus Leuconostoc in the present study, and thus L. fallax must remain in the genus Leuconostoc. The species will probably be reclassified in a novel genus when a phylogenetic relative of this species is found and a significant physiological or biochemical difference is determined between L. fallax and the remaining species of the genus Leuconostoc. A novel species of the genus Leuconostoc, Leuconostoc holzapfelii, was described recently (De Bruyne et al., 2007). Our independent phylogenetic analysis based on 16S rRNA gene sequences showed that $L$. holzapfelii was a member of the $L$. mesenteroides subcluster (data not shown) and this correlated well with the results of De Bruyne et al. (2007). Therefore, a reclassification of $L$. holzapfelii is not needed.

\section{Description of Fructobacillus gen. nov.}

Fructobacillus (Fruc.to.ba.cil'lus. N.L. masc. n. Fructobacillus arbitrarily derived from fructose and Lactobacillus, intended to mean fructose-loving lactic acid-producing bacillus).

Cells are Gram-positive and non-motile rods. Cells usually occur singly or in pairs and in chains. Facultatively anaerobic. Active growth is observed in a broth containing D-fructose as a substrate, and poor growth occurs on Dglucose. Growth in GYP broth is enhanced under aerobic conditions. Colonies are beige, smooth and approximately 1-2 $\mathrm{mm}$ in diameter on FYP agar after incubation for 2 days and are less than $1 \mathrm{~mm}$ in diameter on GYP agar after incubation for 5 days under anaerobic conditions. Growth is enhanced under aerobic conditions on GYP agar and colony size is approximately $1-2 \mathrm{~mm}$ in diameter after incubation for 2 days. Heterofermentative and produce lactic acid, carbon dioxide and acetic acid from D-glucose or D-fructose. Ethanol is not produced. Major lactic acid produced is of the D-isomer. Nitrate is not reduced. Acid is produced from a limited number of carbohydrates, D-glucose and D-fructose. Acid production from D-mannitol is delayed. The optimum temperature for growth is approximately $30{ }^{\circ} \mathrm{C}$, and the optimum $\mathrm{pH}$ for growth is approximately 6.5. Xerotolerant. Cells grow in FYP broth containing $5 \%(\mathrm{w} / \mathrm{v}) \mathrm{NaCl}$ and poorly on $7.5 \%(\mathrm{w} / \mathrm{v}) \mathrm{NaCl}$. Cells grow in a broth containing $40 \%(\mathrm{w} / \mathrm{v})$ D-fructose and poorly on $50 \%(\mathrm{w} /$ v) D-fructose. The DNA G $+\mathrm{C}$ content ranges from 42 to $45 \mathrm{~mol} \%$. The type species is Fructobacillus fructosus.

\section{Description of Fructobacillus fructosus comb. nov.}

Fructobacillus fructosus (fruc.to'sus. N.L. masc. adj. fructosus pertaining to fructose).

Basonym: Lactobacillus fructosus Kodama 1956 (Approved Lists 1980).

Other synonym: Leuconostoc fructosum (Kodama 1956) Antunes et al. 2002.

The description of Fructobacillus fructosus is the same as that given for Leuconostoc fructosum by Antunes et al. (2002).

The type strain is IFO $3516^{\mathrm{T}} \quad\left(=\mathrm{JCM} \quad 1119^{\mathrm{T}}=\mathrm{DSM}\right.$ $20349^{\mathrm{T}}=$ NRIC $1058^{\mathrm{T}}$ ).

\section{Description of Fructobacillus durionis comb. nov.}

Fructobacillus durionis (du.ri.o'nis. N.L. gen. n. durionis of Durio, the generic name of Durio zibenthinus, the durian fruit). 
Basonym: Leuconostoc durionis Leisner et al. 2005.

The description of Fructobacillus durionis is the same as that given for Leuconostoc durionis by Leisner et al. (2005). The type strain is $\mathrm{D}-24^{\mathrm{T}}\left(=\mathrm{LMG} 22556^{\mathrm{T}}=\right.$ CCUG $\left.49949^{\mathrm{T}}\right)$.

\section{Description of Fructobacillus ficulneus comb. nov.}

Fructobacillus ficulneus (fi.cul'ne.us. L. masc. adj. ficulneus of the fig tree).

Basonym: Leuconostoc ficulneum Antunes et al. 2002.

The description of Fructobacillus ficulneus is the same as that given for Leuconostoc ficulneum by Antunes et al. (2002).

The type strain is FS $-1^{\mathrm{T}}\left(=\mathrm{DSM} 13613^{\mathrm{T}}=\mathrm{JCM} 12225^{\mathrm{T}}\right)$.

\section{Description of Fructobacillus pseudoficulneus comb. nov.}

Fructobacillus pseudoficulneus (pseu.do.fi.cul'ne.us. Gr. adj. pseudes false; L. adj. ficulneus - $a-u m$ of the fig-tree and also a bacterial specific epithet; N.L. masc. adj. pseudoficulneus not the true Leuconostoc ficulneum/Fructobacillus ficulneus).

Basonym: Leuconostoc pseudoficulneum Chambel et al. 2006.

The description of Fructobacillus pseudoficulneus is based on the description of Leuconostoc pseudoficulneum as given by Chambel et al. (2006), with the following modification. Cells are rods measuring $0.4-0.6 \times 2-5 \mu \mathrm{m}$ and occur singly or in pairs and in chains.

The type strain is $\mathrm{LC}-51^{\mathrm{T}}\left(=\mathrm{DSM} 15468^{\mathrm{T}}=\operatorname{CECT} 5759^{\mathrm{T}}\right)$.

\section{Acknowledgements}

We are grateful to K. Komagata and L. M. T. Dicks (Department of Microbiology, University of Stellenbosch) for valuable discussions, Y. Yaguchi (Electron Microscope Center, Tokyo University of Agriculture) for advice about the procedures for SEM observations, J. P. Euzéby (Société de Bactériologie Systématique et Vétérinaire and École Nationale Vétérinaire de Toulouse) for advice on naming a novel genus in Latin, B. J. Tindall (Deutsche Sammlung von Mikroorganismen und Zellkulturen $\mathrm{GmbH}$ ) for advice regarding the treatment of a patent strain and R. Tenreiro (Universidade de Lisboa) for the kind donation of $L$. pseudoficulneum strains. Thanks are also due to K. Sonobe (NODAI Culture Collection Center, Tokyo University of Agriculture) for her technical assistance.

\section{References}

Antunes, A., Rainey, F. A., Nobre, M. F., Schumann, P., Ferreira, A. M., Ramos, A., Santos, H. \& da Costa, M. S. (2002). Leuconostoc ficulneum sp. nov., a novel lactic acid bacterium isolated from a ripe fig, and reclassification of Lactobacillus fructosus as Leuconostoc fructosum comb. nov. Int J Syst Evol Microbiol 52, 647-655.

Björkroth, K. J., Geisen, R., Schillinger, U., Weiss, N., De Vos, P., Holzapfel, W. H., Korkeala, H. J. \& Vandamme, P. (2000).
Characterization of Leuconostoc gasicomitatum sp. nov., associated with spoiled raw tomato-marinated broiler meat strips packaged under modified-atmosphere conditions. Appl Environ Microbiol 66, 3764-3772.

Björkroth, K. J., Geisen, R., Schillinger, U., Weiss, N., De Vos, P., Holzapfel, W. H., Korkeala, H. J. \& Vandamme, P. (2001). Leuconostoc gasicomitatum sp. nov. In Validation of Publication of New Names and New Combinations Previously Effectively Published Outside the IJSEM, List no. 79. Int J Syst Evol Microbiol 51, 263-265.

Brosius, J., Dull, T. J., Sleeter, D. D. \& Noller, H. F. (1981). Gene organization and primary structure of a ribosomal RNA operon from Escherichia coli. J Mol Biol 148, 107-127.

Cavalli-Sforza, L. L. \& Edwards, A. W. F. (1967). Phylogenetic analysis models and estimation procedures. Am J Hum Genet 19, 233-257.

Chambel, L., Chelo, I. M., Zé, Zé, L., Pedro, L. G., Santos, M. A. \& Tenreiro, R. (2006). Leuconostoc pseudoficulneum sp. nov., isolated from a ripe fig. Int J Syst Evol Microbiol 56, 1375-1381.

Chelo, I. M., Zé-Zé, L. \& Tenreiro, R. (2007). Congruence of evolutionary relationships inside the Leuconostoc-OenococcusWeissella clade assessed by phylogenetic analysis of the 16S rRNA gene, dnaA, gyrB, rpoC and dnaK. Int J Syst Evol Microbiol 57, 276286.

Collins, M. D., Rodrigues, U. M., Ash, C., Aguirre, M., Farrow, J. A. E., Martinez-Murcia, A., Philips, B. A., Williams, A. M. \& Wallbanks, S. (1991). Phylogenetic analysis of the genus Lactobacillus and related lactic acid bacteria as determined by reverse transcriptase sequencing of 16S rRNA. FEMS Microbiol Lett 77, 5-12.

Condon, S. (1987). Responses of lactic acid bacteria to oxygen. FEMS Microbiol Rev 46, 269-280.

De Bruyne, K., Schillinger, U., Caroline, L., Böhringer, B., Cleenwerck, I., Vancanneeyt, M., De Vuyst, L., Franz, C. M. A. P. \& Vandamme, P. (2007). Leuconostoc holzapfelii sp. nov., isolated from Ethiopian coffee fermentation and assessment of sequence analysis of housekeeping genes for delineation of Leuconostoc species. Int J Syst Evol Microbiol 57, 2952-2959.

Dellaglio, F., Dicks, L. M. T. \& Torriani, S. (1995). The genus Leuconostoc. In Lactic Acid Bacteria, vol. 2. The Genera of Lactic Acid Bacteria, pp. 235-238. Edited by B. J. B. Wood \& W. H. Holzapfel. Blackie Academic \& Professional.

Dellaglio, F., Felis, G. E., Castioni, A., Torriani, S. \& Germond, J. E. (2005). Lactobacillus delbrueckii subsp. indicus subsp. nov., isolated from Indian dairy products. Int J Syst Evol Microbiol 55, 401-404.

DeMoss, R. D., Bard, R. C. \& Gunsalus, I. C. (1951). The mechanism of heterolactic fermentation: a new route of ethanol fermentation. J Bacteriol 62, 499-511.

Eisen, J. A. (1995). The RecA protein as a model molecule for molecular systematic studies of bacteria: comparison of trees of RecAs and 16S rRNAs from the same species. J Mol Evol 41, 1105-1123.

Endo, A. \& Okada, S. (2005). Lactobacillus satsumensis sp. nov., isolated from mashes of shochu, a traditional Japanese distilled spirit made from fermented rice and other starchy materials. Int J Syst Evol Microbiol 55, 83-85.

Farrow, J. A. E., Facklam, R. R. \& Collins, M. D. (1989). Nucleic acid homologies of some vancomycin-resistant leuconostocs and description of Leuconostoc citreum sp. nov. and Leuconostoc pseudomesenteroides sp. nov. Int J Syst Bacteriol 39, 279-283.

Felis, G. E., Dellaglio, F., Mizzi, L. \& Torriani, S. (2001). Comparative sequence analysis of a $\operatorname{rec} A$ gene fragment brings new evidence for a change in the taxonomy of the Lactobacillus casei group. Int J Syst Evol Microbiol 51, 2113-2117.

Felsenstein, J. (1985). Confidence limits on phylogenies: an approach using the bootstrap. Evolution 39, 783-791. 
Felsenstein, J. (2005). PHYLIP (Phylogeny Inference Package), version 3.6. Distributed by the author. Department of Genome Sciences, University of Washington, Seattle, USA.

Garvie, E. I. (1960). The genus Leuconostoc and its nomenclature. J Dairy Res 27, 283-292.

Higashiguchi, D. T., Husseneder, C., Grace, J. K. \& Berestecky, J. M. (2006). Pilibacter termitis gen. nov., sp. nov., a lactic acid bacterium from the hindgut of the Formosan subterranean termite (Coptotermes formosanus). Int J Syst Evol Microbiol 56, 15-20.

Jian, W. \& Dong, X. (2002). Transfer of Bifidobacterium inopinatum and Bifidobacterium denticolens to Scardovia inopinata gen. nov., comb. nov., and Parascardovia denticolens gen. nov., comb. nov., respectively. Int J Syst Evol Microbiol 52, 809-812.

Johnson, M. K. \& McCleskey, C. S. (1957). Studies on the aerobic carbohydrate metabolism of Leuconostoc mesenteroides. J Bacteriol 74, $22-25$.

Keenan, T. W. (1968). Production of acetic acid and other volatile compounds by Leuconostoc citrovorum and Leuconostoc dextranicum. Appl Microbiol 16, 1881-1885.

Kim, J., Chun, J. \& Han, H. U. (2000). Leuconostoc kimchii sp. nov., a new species from kimchi. Int J Syst Evol Microbiol 50, 1915-1919.

Kim, B., Lee, J., Jang, J., Kim, J. \& Han, H. (2003). Leuconostoc inhae sp. nov., a lactic acid bacterium isolated from kimchi. Int J Syst Evol Microbiol 53, 1123-1126.

Kimura, M. (1980). A simple method for estimating evolutionary rates of base substitutions through comparative studies of nucleotide sequences. J Mol Evol 16, 111-120.

Kluge, A. G. \& Farris, F. S. (1969). Quantitative phyletics and the evolution of anurans. Syst Zool 18, 1-32.

Kodama, R. (1956). Studies on the nutrition of lactic acid bacteria. Part IV. Lactobacillus fructosus nov. sp., a new species of lactic acid bacteria. J Agric Chem Soc Jpn 30, 705-708 (in Japanese).

Leisner, J. J., Vancanneyt, M., Goris, J., Christensen, H. \& Rusul, G. (2000). Description of Paralactobacillus selangorensis gen. nov., sp. nov., a new lactic acid bacterium isolated from chili bo, a Malaysian food ingredient. Int J Syst Evol Microbiol 50, 19-24.

Leisner, J. J., Vancanneyt, M., van der Meulen, R., Lefebvre, K., Engelbeen, K., Hoste, B., Laursen, B. G., Bay, L., Rusul, G. \& other authors (2005). Leuconostoc durionis sp. nov., a heterofermenter with no detectable gas production from glucose. Int J Syst Evol Microbiol 55, 1267-1270.

Lucey, C. A. \& Condon, S. (1986). Active role of oxygen and NADH oxidase in growth and energy metabolism of Leuconostoc. J Gen Microbiol 132, 1789-1796.

Martinez-Murcia, A. J. \& Collins, M. D. (1991). A phylogenetic analysis of an atypical leuconostoc: description of Leuconostoc fallax sp. nov. FEMS Microbiol Lett 82, 55-60.

Martinez-Murcia, A. J. \& Collins, M. D. (1992). Leuconostoc fallax sp. nov. In Validation of the Publication of New Names and New Combinations Previously Effectively Published Outside the IJSB, List no. 40. Int J Syst Bacteriol 42, 191-192.
Morse, R., Collins, M. D., O'Hanlon, K., Wallbanks, S. \& Richardson, P. T. (1996). Analysis of the $\beta^{\prime}$ subunit of DNA-dependent RNA polymerase does not support the hypothesis inferred from 16S rRNA analysis that Oenococcus oeni (formerly Leuconostoc oenos) is a techytelic (fast-evolving) bacterium. Int J Syst Bacteriol 46, 1004-1009.

Naser, S. M., Thompson, F. L., Hoste, B., Gevers, D., Dawyndt, P., Vancanneyt, M. \& Swings, J. (2005). Application of multilocus sequence analysis (MLSA) for rapid identification of Enterococcus species based on rpoA and pheS genes. Microbiology 151, 2141-2150.

Naser, S. M., Vancanneyt, M., Hoste, B., Snauwaert, C. \& Swings, J. (2006). Lactobacillus cypricasei Lawson et al. 2001 is a later heterotypic synonym of Lactobacillus acidipiscis Tanasupawat et al. 2000. Int J Syst Evol Microbiol 56, 1681-1683.

Rachman, C. N., Kabadjova, H., Prévost, H. \& Dousset, X. (2003). Identification of Lactobacillus alimentarius and Lactobacillus farciminis with 16S-23S rDNA intergenic spacer region polymorphism and PCR amplification using species-specific oligonucleotide. J Appl Microbiol 95, 1207-1216.

Saitou, N. \& Nei, M. (1987). The neighbor-joining method: a new method for reconstructing phylogenetic trees. Mol Biol Evol 4, 406425.

Sakamoto, M. \& Komagata, K. (1996). Aerobic growth of and activities of $\mathrm{NADH}$ oxidase and $\mathrm{NADH}$ peroxidase in lactic acid bacteria. J Ferment Bioeng 82, 210-216.

Shaw, B. G. \& Harding, C. D. (1989). Leuconostoc gelidum sp. nov. and Leuconostoc carnosum sp. nov. from chill-stored meats. Int J Syst Bacteriol 39, 217-223.

Skerman, V. B. D., McGowan, V. \& Sneath, P. H. A. (editors) (1980). Approved lists of bacterial names. Int J Syst Bacteriol 30, 225-420.

Sneath, P. H. A., Mair, N. S., Sharpe, M. E. \& Holt, J. G. (editors) (1986). Bergey's Manual of Systematic Bacteriology, vol. 2, Baltimore: Williams \& Wilkins.

Thompson, J. D., Gibson, T. J., Plewniak, F., Jeanmougin, F. \& Higgins, D. G. (1997). The CLUSTAL_X windows interface: flexible strategies for multiple sequence alignment aided by quality analysis tools. Nucleic Acids Res 25, 4876-4882.

Torriani, S., Felis, G. E. \& Dellaglio, F. (2001). Differentiation of Lactobacillus plantarum, L. pentosus, and L. paraplantarum by recA gene sequence analysis and multiplex PCR with recA gene-derived primers. Appl Environ Microbiol 67, 3450-3454.

Van de Peer, Y., De Rijk, P., Wuyts, J., Winkelmans, T. \& De Watcher, R. (2000). The European small subunit ribosomal RNA database. Nucleic Acids Res 28, 175-176.

Van Tieghem, P. (1878). Sur la gomme du sucerie (Leuconostoc mesenteroides). Ann Sci Nat Bot 7, 180-203.

Vancanneyt, M., Zamfir, M., de Wachter, M., Cleenwerck, I., Hoste, B., Rossi, F., Dellaglio, F., de Vuyst, L. \& Swings, J. (2006). Reclassification of Leuconostoc argentinum as a later synonym of Leuconostoc lactis. Int $J$ Syst Evol Microbiol 56, 213-216.

Zavaleta, A. I., Martinez-Murcia, A. J. \& Rodriguez-Valera, F. (1996). $16 \mathrm{~S}-23 \mathrm{~S}$ rDNA intergenic sequences indicate that Leuconostoc oenos is phylogenetically homogeneous. Microbiology 142, 2105-2114. 